\title{
Cellular and Molecular Aspects of Monoamine Neurotransmitter Transporters
}

\author{
Shigeo Kitayama and Toshihiro Dohi \\ Department of Pharmacology, Hiroshima University School of Dentistry, Kasumi 1-2-3, Minami-ku, Hiroshima 734, Japan
}

Received July 23, 1996

\begin{abstract}
Neurotransmitter transporters terminate synaptic neurotransmission by accumulating neurotransmitters once again after release in a sodium- and chloride-dependent fashion. The availability of the cloned neurotransmitter transporters has allowed investigation into the roles of these transporters in neuronal function. Molecular biological and protein engineering studies including in vitro site-directed mutagenesis, chimera formation of several transporter clones, or epitope-tagging various regions of transporter proteins, have revealed the topology and functionally mapped the transporter proteins. Monoamine neurotransmitter transporters such as those for dopamine, norepinephrine and serotonin are of interest, since they are a target of drugs of abuse and are involved in neuronal disorders including Parkinson's disease and depression. Therefore, elucidating the molecular basis of these transporters may clarify these problems and help develop treatments with which to combat these disorders and drug abuse.
\end{abstract}

Keywords: Neurotransmitter transporter, Monoamine, Antidepressant, Drug abuse, Parkinson's disease

Neurotransmitters released from nerve terminals are taken up by a specific transport system located on the plasma membrane of nerve terminals or surrounding glia cells, which immediately terminates synaptic neurotransmission. This neurotransmitter transporter system plays an important role in neuronal functions by fine-tuning neurotransmission. When transporter functions are suppressed, excess neurotransmitters released into the synaptic cleft accumulate, which causes an increase in excitation at the initial phase followed by various disturbances of neurotransmission.

The uptake, especially that of monoamines, is of particular interest because these neurotransmitters are involved in neuronal disorders such as depression (1). Since the discovery of the parkinsonism-inducing neurotoxin, $\mathrm{N}$-methyl-4-phenyl-1,2,5,6-tetrahydropyridine (MPTP), efforts have been made to clarify the role of transporters in the development of this disease $(2,3)$. Furthermore, monoamine transporters participate in the action of drugs of abuse. The reinforcing properties of psychostimulants including cocaine correlate positively with their ability to inhibit dopamine uptake through the dopamine transporter (DAT) (4).

The $\gamma$-aminobutyric acid (GABA) transporter (GAT) cDNA was first originally cloned from rat brain by protein purification and subsequent screening of a library with oligonucleotides based on the amino acid sequences of peptides released from the purified protein by protease digestion (5). Thereafter, the human norepinephrine transporter (NET) was identified by expression cloning using an $\left[{ }^{125} I\right]$-labeled transporter substrate (6). One year later, the cDNAs of transporters for dopamine $(7-10)$, serotonin $(11,12)$, glycine $(13-15)$, taurine $(16-18)$, proline (19), betaine/GABA (20) and creatine (21) were cloned by means of DNA sequence homology and polymerase chain reaction (PCR). These transporters constitute a gene family, emphasizing the importance of gene analyses and the structure-function relationship. The

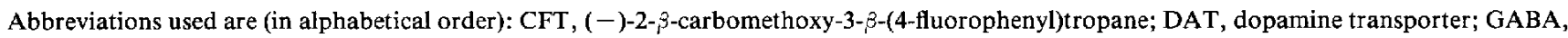
$\gamma$-aminobutyric acid; GAT, GABA transporter; MPP ${ }^{+}, 1$-methyl-4-phenylpyridinium; MPTP, $N$-methyl-4-phenyl-1,2,5,6-tetrahydropyridine; NET, norepinephrine transporter; PKC, protein kinase C; SERT, serotonin transporter; TM, transmembrane. 
homology of amino acid sequence among the monoamine neurotransmitter transporters is high, and they constitute a subfamily. Transporters for glutamate and aspartate, cloned later by protein purification, belong to another gene family with less homology to GABA and other neurotransmitter transporters (22-24). A third group of neurotransmitter transporters includes vesicular transporters for neurotransmitters located at the synaptic vesicle membranes, where they play an important role in neurotransmitter accumulation and storage. To date, one acetylcholine (25) and two monoamine transporters $(26-28)$ have been cloned.

In this review, we describe the cellular and molecular biology of the plasma membrane monoamine neurotransmitter transporters. We also review the pharmacological aspects of their functional mechanisms in relation to neuronal disorders and drugs of abuse.

Molecular biology of monoamine neurotransmitter transporters

The cloned cDNAs for the $\mathrm{Na}^{+}$- and $\mathrm{Cl}^{-}$-dependent transporters for dopamine $(7-10,29,30)$, norepinephrine $(6,31)$ and serotonin $(11,12,32-36)$ predict a shared structure. They consist of about 600 amino acids includ- ing 12 hydrophobic segments that are likely to be transmembrane domains. It is predicted that both the amino and carboxy termini are intracellular because they lack a signal peptide sequence (Fig. 1). Members of this family also have a large second extracellular loop between putative transmembrane (TM) regions 3 (TM3) and 4 (TM4), with consensus sites for $N$-linked glycosylation. In addition, there are consensus sites for phosphorylation in the intracellular domains, such as for protein kinase $\mathrm{C}$ (PKC), cAMP-dependent protein kinase and also for $\mathrm{Ca}^{2+} /$ calmodulin-dependent protein kinase (Fig. 1 and Table 1).

Table 1 also summarizes the chromosomal localization of these transporter genes (32-34, 37-42). At present, there is little information regarding the relationship between these genes and inherited diseases (44-46).

Studies on the distribution of monoamine neurotransmitter transporters have shown that their expression is localized within cells where the corresponding neurotransmitters are synthesized and stored. DAT mRNA is expressed at high levels in dopaminergic cells of the substantia nigra pars compacta (SNC) as well as the ventral tegmental area (VTA), and the transporter proteins are abundant in the dopaminergic projection areas of the basal ganglia $(47-50)$.

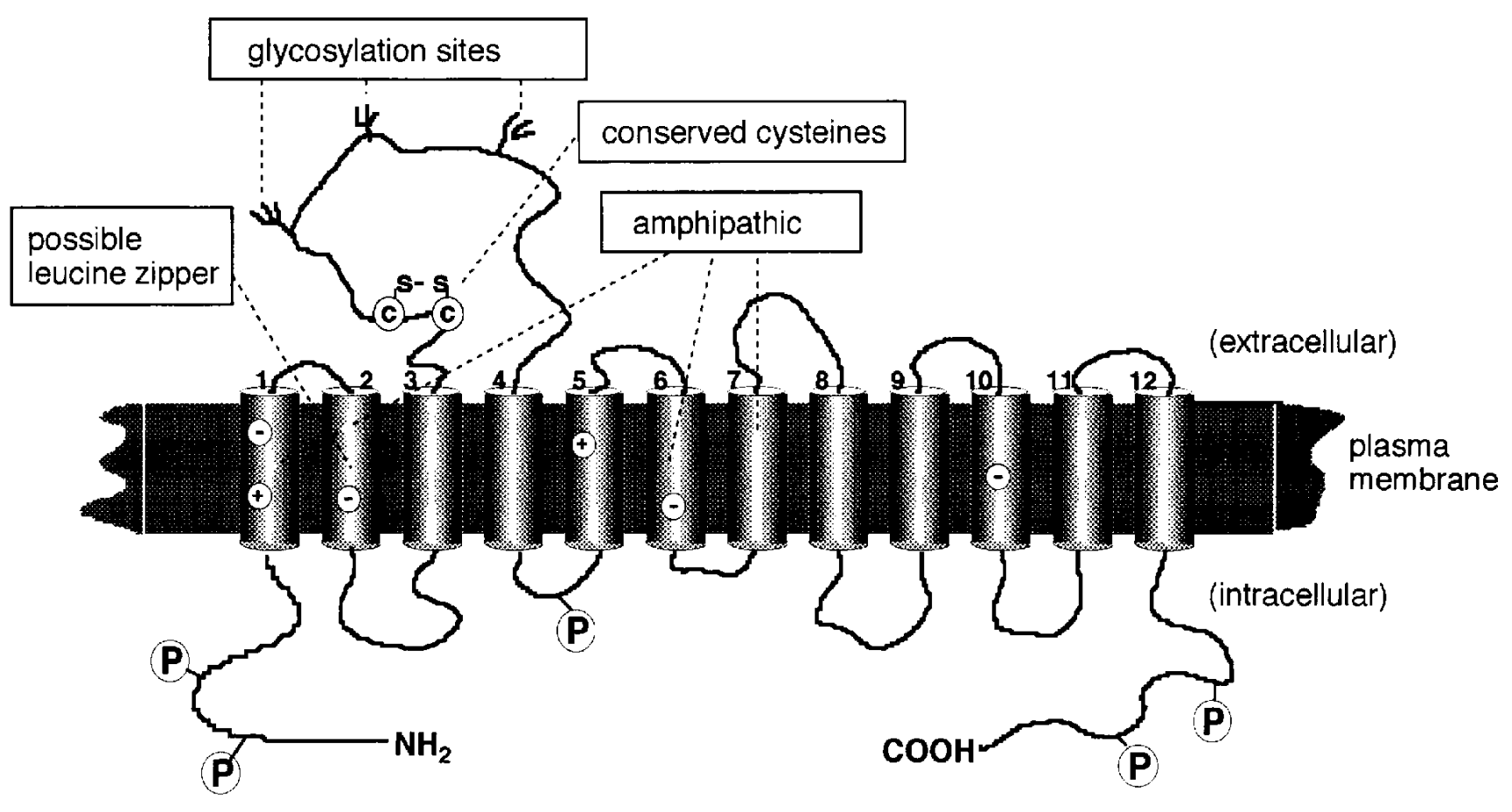

\section{$\Theta \Theta$ : charged amino acid $\quad($ P : possible phosphorylation site}

Fig. 1. Predicted membrane topology and specific structural features of monoamine neurotransmitter transporters. 
Table 1. Monoamine neurotransmitter transporters

\begin{tabular}{|c|c|c|c|c|c|c|c|}
\hline Transporter & Species & $\begin{array}{l}\text { Amino } \\
\text { acid }\end{array}$ & $\begin{array}{l}\text { mRNA size } \\
(\mathrm{kb})\end{array}$ & $\begin{array}{l}\text { Chromosom } \\
\text { assignment }\end{array}$ & Distribution & $\begin{array}{l}\text { Putative phosphorylation } \\
\text { sites }\end{array}$ & References \\
\hline \multirow[t]{3}{*}{ Dopamine } & rat & 619 & 3.6 & - & brain & PKA, PKC, CaMKII & $7-9$ \\
\hline & human & 620 & - & $5 \mathrm{p} 15.3$ & brain & PKA, PKC, CaMKII & $29,30,37-39$ \\
\hline & mouse & - & 3.7 & 13 & brain & - & 39 \\
\hline Norepinephrine & human & 617 & 5.8 & $16 \mathrm{q} 13-\mathrm{q} 21$ & brain, adrenal medulla & PKA, PKC & $6,40-43$ \\
\hline \multirow[t]{4}{*}{ Serotonin } & rat & 630 & $3.1,3.7$ & - & $\begin{array}{l}\text { brain, adrenals, gut, stomach, } \\
\text { kidney, uterus, spleen }\end{array}$ & PKA, PKC, CaMKII & 11,12 \\
\hline & human & 630 & $3,4.9,6.8$ & $17 q 12$ & $\begin{array}{l}\text { brain, adrenals, gut, stomach, } \\
\text { kidney, uterus, spleen, placenta }\end{array}$ & PKA, PKC, CaMKII & 32,33 \\
\hline & mouse & - & - & 11 & bгаiп & - & 34 \\
\hline & Drosophila & 581 & 3.3 & - & nervous system & PKA, PKC & 35,36 \\
\hline
\end{tabular}

PKA, cAMP-dependent protein kinase; PKC, protein kinase C; CaMKII, $\mathrm{Ca}^{2+} /$ calmodulin-dependent protein kinase II.

NET (51-53) and serotonin transporter (SERT) $(54,55)$ mRNAs and proteins have been detected by in situ hibridization and immunohistochemistry with their specific antibodies in brain regions where there are markers for norepinephrine or serotonin neurons.

Although astrocytes in primary culture uptake serotonin and catecholamines (56), there is no evidence indicating the expression of mRNA for monoamine neurotransmitter transporters in glial cells.

\section{Structure-function relationship}

By means of in vitro site-directed mutagenesis, chimera formation and protease digestion and reconstitution of purified transporter protein, an increasing body of evidence has predicted the structure-function relationship of the transporters. In this section, we address the following issues to clarify and summarize the current understanding of the monoamine neurotransmitter transporters: 1) the domains of the transporter that participate in substrate/ligand recognition and whether or not they overlap; if recognition sites for the substrate and uptake inhibitor partially overlap, whether or not compounds can be developed that specifically antagonize uptake inhibition while it spares substrate transport; 2) the transport process operates and whether or not it is reversible; if uptake inhibitors act on reversed transport in a similar manner to uptake inhibition, whether or not uptake and release through the transporter can be distinguished; and 3) the role ions play in the transport process; the nature of the structure and function of the transporter and channel.

\section{Specificity and reversibility of transporter}

DAT can accumulate dopaminergic neurotoxin with structural features resembling those of dopamine, such as 1-methyl-4-phenylpyridinium ( $\left.\mathrm{MPP}^{+}\right)$, an active metabolite of $\operatorname{MPTP}(2,3)$. The expression of a cloned DAT cDNA in several cell lines including non-neuronallyderived $\mathrm{COS}$ cells caused massive $\mathrm{MPP}^{+}$accumulation, resulting in $\mathrm{MPP}^{+}$toxicity $(57,58)$. However, Pifl et al. (58) found that in non-neuronally-derived cells such as COS-7, CHO (Chinese hamster ovary), and $\mathrm{Ltk}^{-}$cells expressing DAT, the $\mathrm{K}_{\mathrm{m}}$ of $\mathrm{MPP}^{+}$was at least tenfold higher than that in neuronally-derived cell lines such as NG108-15, NS20Y and SK-N-MC. Gu et al. (59) demonstrated that both LLC-PK $_{1}$ cells expressing DAT and NET accumulate both dopamine and norepinephrine at a similar substrate specificity except for some kinetic differences. Therefore, the question arises as to whether the transport processes for various substrates involve different rate-limiting steps for each substrate or different rates of translocation that may be affected by bound substrate.

By analogy with the structural features of adrenergic receptors determined molecular biologically by Strader et al. $(60-62)$, the importance of polar amino acid residues within transmembrane domains for substrate transport and ligand binding in the DAT has been examined by means of site-directed mutagenesis by Uhl's group. They have shown that an aspartate in TMl and two serine residues in TM7 of rat DAT are essential for dopamine uptake, although the latter amino acid replacement has less effect upon the binding of the cocaine analogue $(-)$ 2-3-carbomethoxy-3-3-(4-fluorophenyl)tropane (CFT) (63). These amino acids are conserved in the monoamine transporters but not in other amino acid transporters such as those for GABA. Uhl et al. suggested that these amines bound through these residues, the negative group binding to the protonated amine and the serine hydroxy group hydrogen bonding with the catechol moiety of the substrates. 
These investigators further demonstrated that replacing another two serines in TM7 located near the cytoplasmic side with alanine or glycine increased $\mathrm{MPP}^{+}$uptake, while the affinity for CFT decreased (64). $\mathrm{MPP}^{+}$uptake was also increased without affecting that of dopamine in a mutant DAT in which polar amino acids located in TM11 were replaced by alanine (64). Kinetic analyses revealed an increased $V_{\max }$ with an unaltered $K_{m}$ in this TM7 mutant, while the affinity for $\mathrm{MPP}^{+}$increased with a change in the $V_{\max }$ in the TM11 mutant. These results suggested that specific recognition site(s) for different substrates could be recognized despite the quantitative dissociation between dopamine and $\mathrm{MPP}^{+}$uptake.

Buck and Amara (65) addressed this issue by constructing a series of chimeric proteins containing parts of DAT and NET. Unlike analyses of site-directed or deletion mutants with negative changes in function, chimeras often provide an assayable phenotype that allows positive inferences to be drawn from functions associated with discrete protein domains. These authors demonstrated that TM2 and TM3, as well as TM10 and TM11, influence the apparent affinity for substrates, including MPP ${ }^{+}$. Furthermore, TMs4-8 might affect the relative rate at which the substrate is accumulated, namely translocation of a transporter with a recognized substrate.

The relatively higher $V_{\max }$ of DAT than NET for MPP $^{-}$uptake (65) may contribute to the selective neurotoxic effects of $\mathrm{MPP}^{+}$on dopaminergic neurons, although the affinity of NET for $\mathrm{MPP}^{+}$is higher than that of DAT. In other words, the initial velocity of $\mathrm{MPP}^{+}$is more critical for its toxicity than its affinity.

Kinetic analyses of $\left[{ }^{3} \mathrm{H}\right]$ dopamine and $\left[{ }^{3} \mathrm{H}\right] \mathrm{MPP}^{+}$uptake revealed that $K_{m}$ differed as well as the $V_{\max }$ (see Table 2$)$. The initial velocity of apparent uptake $\left(\mathrm{V}_{\max }\right)$ represents a transport cycle that depends not only on the translocation rate of the substrate from its initial extracellular binding site to an intracellular releasable state, but also on re-orientation of the transporter from the intracellular to the extracellular facing state. This reorientation seems independent of the substrate. Since the $V_{\max }$ of the transport of various substrates differs, the substrate bound in the initial state may affect the subsequent translocation rate. On the other hand, the affinity for a substrate when the transporter is in the intracellular facing state, participates in transport cycles. At present there is no information regarding this question. However, $\mathrm{MPP}^{+}$has a greater efflux rate than dopamine in COS cells expressing rat DAT, suggesting the latter may be a factor in the greater $\mathrm{V}_{\max }$ for $\mathrm{MPP}^{+}$than for dopamine (66).

There is growing evidence that transporters release neurotransmitters in physiological and disease states (for a review, see ref. 67). Transporter-mediated efflux of the monoamine neurotransmitters has also been demonstrated (67). Eshleman et al. (68) studied transporter-mediated dopamine release in $\operatorname{COS}$ cells transfected with the human DAT cDNA. This expression system provides a useful model of the transporter-mediated release of neurotransmitters, because it lacks vesicular storage, an exocytotic release mechanism and electrical excitability of the plasma membrane. They showed that GBR12935 and mazindol, specific inhibitors of dopamine uptake, significantly decreased dopamine release. Although cocaine by itself failed to inhibit dopamine release, it antagonized the effects of GBR12935 and mazindol on dopamine efflux. In contrast, Wall et al. (69) have found that neither cocaine nor mazindol affect $\mathrm{MPP}^{+}$efflux through the rat DAT expressed in LLC-PK cells. These authors explained these discrepancies as a result of the cell lines used or a difference in the transient or stable expression of the transporter. Kitayama et al. (66) showed that the rate of reversed transport of $\mathrm{MPP}^{+}$was greater than that of dopamine and that cocaine, GBR12935 and nomifensine reduced $\mathrm{MPP}^{+}$, but not dopamine efflux.

Table 2. Pharmacological properties of monoamine neurotransmitter transporters

\begin{tabular}{|c|c|c|c|c|c|c|c|}
\hline Transporter & $\begin{array}{l}\mathrm{K}_{\mathrm{m}}(\mu \\
\text { neuro }\end{array}$ & $\begin{array}{l}\text { M) for each } \\
\text { transmitter }\end{array}$ & $\begin{array}{l}\text { MPP }^{+} \text {uptake } \\
\mathbf{K}_{\mathrm{m}}(\mu \mathrm{M})\end{array}$ & $\begin{array}{l}\mathrm{MPP}^{+} \text {uptake } \\
\mathrm{V}_{\max }\left(\mathrm{DA} / \mathrm{MPP}^{+}\right)\end{array}$ & Inhibitors & Toxins & References \\
\hline \multirow[t]{3}{*}{ Dopamine } & DA & $0.3-1.2$ (rat) & $\begin{array}{l}16.4-27.6 \\
\text { (rat) }\end{array}$ & $\begin{array}{l}1: 1.8-1: 2.1 \\
\text { (rat) }\end{array}$ & $\begin{array}{l}\text { mazindol, } \\
\text { GBR12909, }\end{array}$ & $\begin{array}{l}\mathrm{MPP}^{+} \text {, } \\
\text { amphetamine }\end{array}$ & $7-10,30,31,64,65$ \\
\hline & & 31.5 (cow) & & & GBR12935, & & \\
\hline & & 1.2 (human) & & & nomifensine, cocaine & & \\
\hline Norepinephrine & NE & 0.5 (human) & 0.4 (human) & $1: 1$ (human) & $\begin{array}{l}\text { mazindol, desipra- } \\
\text { mine, cocaine }\end{array}$ & $\begin{array}{l}\mathrm{MPP}^{+} \text {, } \\
\text { amphetamine }\end{array}$ & 6,65 \\
\hline \multirow[t]{3}{*}{ Serotonin } & 5-HT & 0.5 (rat) & - & - & paroxetine, & MDMA (ecstacy), & $11,12,32,33,35,36$ \\
\hline & & 0.5 (human) & & & chlorimipramine, & amphetamine & \\
\hline & & 0.6 (Drosophila) & & & fluoxetine, cocaine & & \\
\hline
\end{tabular}

GBR12909, 1-[2-[bis(4-fluorophenyl)methoxy]ethyl]-4-[3-phenylpropyl]pirerazine; GBR12935, 1-[2-(diphenylmethoxy)ethyl]-4-[3-phenylpropyl]pirerazine; MDMA, 3,4-methylenedioxy-methamphetamine. 
These results suggested that substrate specificity is involved in the reversed transport to uptake inhibitors.

Besides the critical role of neurotransmitter uptake by the transporters in terminating fast synaptic transmission, the transporter-mediated release of neurotransmitters (reversed transport) is also essential in some tissues to maintain synaptic basal activity for neurotransmission: for example, normal inhibition by GABA distributed by reversed transport from neurons and glia. During et al. (70) have demonstrated the role of hippocampal GAT function in temporal-lobe epilepsy. They suggested that temporal-lobe epilepsy is characterized in part by a loss of glutamate-stimulated GABA release that is secondary to a reduction in the number of GATs. It is important to clarify the mechanism of reversed transport, because there is less information on the effect of uptake inhibitors on this process. Several studies have shown a paradoxical effect of GABA uptake inhibitors to facilitate seizures $(71,72)$. Furthermore, the nature of blockers that can be transported or not might affect different transporter functions in different states.

\section{Permeation pathway}

The transport of dopamine, norepinephrine and serotonin depends on $\mathrm{Na}^{+}, \mathrm{Cl}$ or $\mathrm{K}^{+}$. This was demonstrated by measuring the equilibrium of substrate/ion distribution outside and inside vesicles or the flux rates of substrate described by the apparant affinity for substrate $\left(K_{m}\right)$ and the initial velocity $\left(V_{\max }\right)$ in modifying ion concentrations in incubation solution. Also, competitive antagonist binding to the membrane preparations containing transporter proteins reveals the stoichiometry of ions required for ligand-transporter interaction (for a review, see ref. 73). These procedures indeed provide the stoichiometry of substrates and ions. However, they do not disclose whether or not the ions required are cotransported.

The electrophysiological approach has only occasionally been taken, because the charge transfer through the transporter associated with the substrate transport cycle $\left(1-10^{4} / \mathrm{sec}\right)$ is much lower than the elementary current for channels $\left(>10^{7} / \mathrm{sec}\right)$. Furthermore, the considerably large current mediated by co-existing channels in some preparations hinder the transport current. Nevertheless, the transporter currents for glutamate (74), GABA (75) and serotonin (76) have been documented.

Transport mechanisms can be investigated electrophysiologically by expressing the cloned neurotransmitter transporters in mammalian cell lines and also in Xenopus laevis oocytes. Initially, the electrogenicity of GABA (77) and glutamate (78) transport was demonstrated in Xenopus laevis oocytes expressing each transporter. Lester and his group have investigated transporter currents in Xenopus laevis oocytes expressing GAT (79) and SERT (80) in more detail. The specific features of the transporter currents are as follows: 1) GABA-induced and GABA-independent currents occur in oocytes expressing GAT (79). In the absence of GABA, transporter-mediated current induced by jumping the membrane voltage is transient and capacitive. The current induced by GABA increases with hyperpolarization and with increasing concentrations of GABA, $\mathrm{Na}^{-}$or $\mathrm{Cl}^{-}$. At low GABA concentrations, the transporter current is independent of membrane potentials, and extracellular GABA is rate-limiting. At a higher concentration of GABA, a voltage-dependent, $\mathrm{Na}^{+}$rate-limiting mechanism operates. 2) The stoichiometry of SERT for serotonin, $\mathrm{Na}^{+}, \mathrm{Cl}^{-}$and $\mathrm{K}^{+}$obtained from studies using radiolabeled ligands and membrane vesicle preparations predicts the electroneutral transport of serotonin. Parallel measurements of $\left[{ }^{3} \mathrm{H}\right]$ serotonin uptake and $3 \beta-\left(4^{\prime}-\right.$ [ ${ }^{125}$ I]iodophenyl)tropane-2, 3 -carboxylic acid methyl ester ([25] ${ }^{125}$ TI-55) SERT selective ligand binding in Xenopus laevis oocytes reveal transport rates as small as $1 / \mathrm{sec}(80)$. However, quite high transporter currents involved several conductive states: i) substrate transport-associated current, ii) transient inward current and iii) outward leak current. These results suggest that the ionic mechanisms of transporter function is not as simple as that predicted by the classical theory; therefore, the authors advocated the notion of the transporter permeation pathway being like an ion channel.

All SERT-mediated currents are sensitive to serotonin uptake blockers (80). Although the physiological relevance of substrate-independent currents remains obscure, these results indicate a new avenue of transporter research.

Galli et al. (81) demonstrated that whole-cell voltageclamped HEK-293 (human embryonic kidney) cells stably expressing human NET generate norepinephrineinduced, $\mathrm{Na}^{+}$-dependent currents and norepinephrineindependent transient currents, both of which were blocked by anti-depressants and cocaine. The features of NET and SERT currents were somewhat similar. However, there were intrinsic properties unique to NET. These authors concluded that $\mathrm{Na}^{+}$does not contribute to the transient current and that the pre-steady-state currents resulted from an internal movement of a charge confined to the membrane and localized to the transporter, probably involving the loading and unloading of $\mathrm{Cl}^{-}$. This explanation is in agreement with other reports regarding the $\mathrm{Cl}^{-}$-dependence of antagonist binding (82, 83).

Based on the results described above, Lester et al. (84) classified transporters into types 1.1 for GAT, 1.2 for SERT and 2 for glutamate transporters, although GAT 
and SERT are about $60 \%$ homologous and belong to the same gene subfamily of neurotransmitter transporters. $\mathrm{NET}$, in fact, constitutes a different class from SERT based on the results described above, even though they are closer than GAT. Furthermore, there are different modes of transporter currents within the glutamate transporter family (85).

Figure 2 describes the molecular events producing these currents, that are most common to neurotransmitter

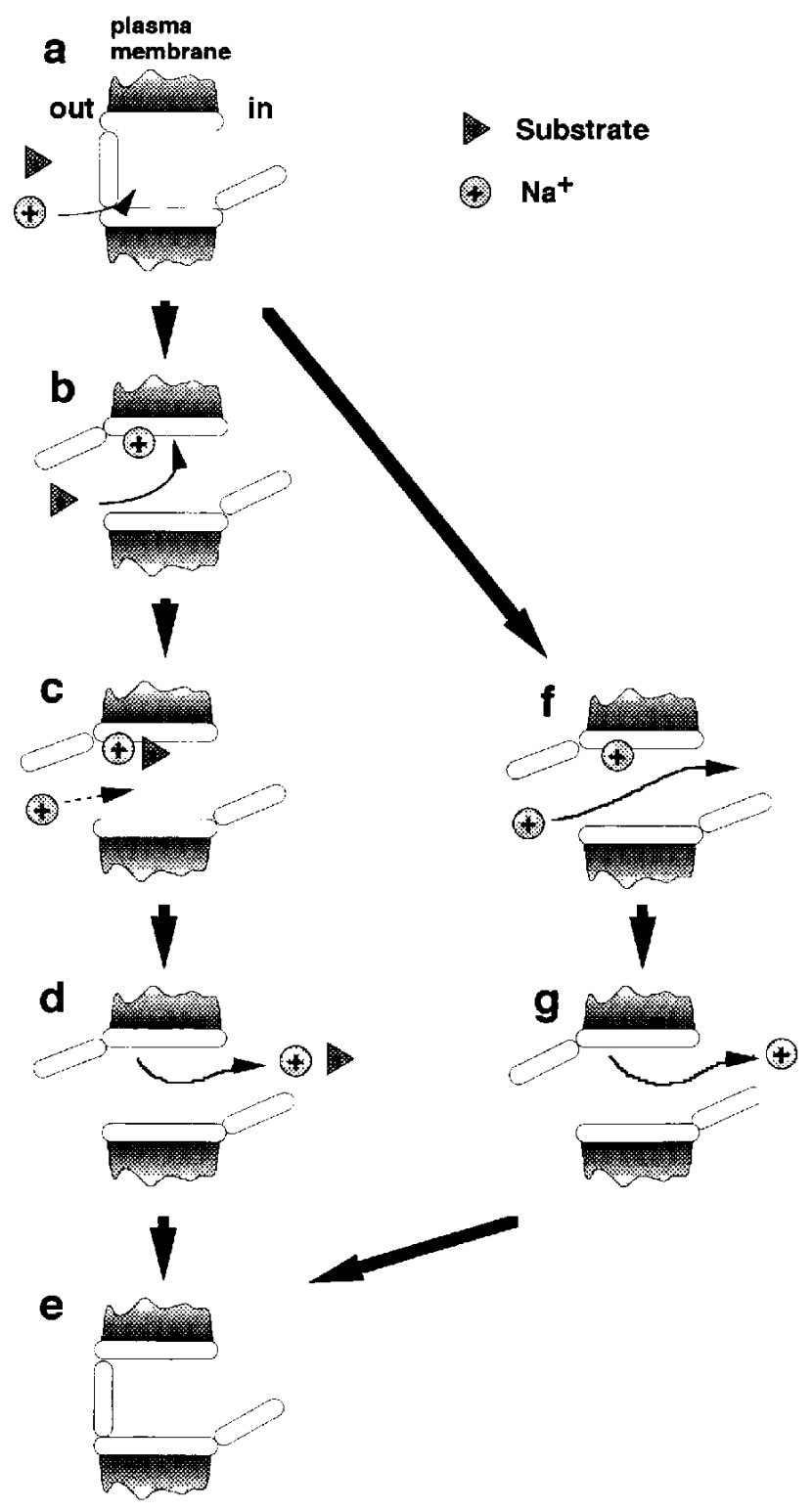

Fig. 2. Schematic illustration describing the behavior of a transporter according to the model proposed by electrophysiological studies. An alternating-access model based on the results from electrophysiological studies indicating a channel-like permeation pathway for both substrates and co-transported ions, as well as non-coordinating flux of ions during gating and non-gating by substrate. transporters. This is a simple model composed of the interaction of a transporter with a substrate and $\mathrm{Na}^{+}$. Chloride ions and/or $\mathrm{K}^{+}, \mathrm{H}^{+}$are excluded from this model because the nature of their involvement differs among transporters. At the resting state shown in "a", $\mathrm{Na}^{+}$can access its binding site, producing the capacitive current observed in GAT and SERT. In the presence of a substrate, the transporter allows it to bind to its recognition site (b). This leads to a conformational change of the transporter, rendering it able to translocate the substrate and ion into the cytoplasm by the driving force of a $\mathrm{Na}^{+}$gradient (d), but an alternative state of $\mathrm{Na}^{+}$gating arises during substrate binding (c). In the absence of substrate, $\mathrm{Na}^{+}$binding causes a conformational change of the transporter, causing it to pass through the $\mathrm{Na}^{+}$-like channel (f).

Kitayama et al. (86) developed a means of intracellularly recording the dopamine concentration using a voltammetric analyzer with a carbon electrode placed intracellularly in Xenopus laevis oocytes expressing rat DAT. The results demonstrated the bi-directional transport of dopamine through the expressed DAT. The method provides measurement with fine time resolution, and thus simultaneous measurement of transporter currents using voltage-clamp may generate more direct evidence of the mechanisms involved in substrate/ion transport and interaction. Furthermore, a combination with site-directed mutagenesis, deletion and chimera formation will provide more details of transport mechanisms.

\section{Drugs that affect transporter functions}

Since monoamine neurotransmitter transporters are a target for various drugs including antidepressants, psychostimulants and neurotoxins, much evidence concerning the pharmacology of monoamine neurotransmitter transporters has been accumulated by investigating the binding properties of radiolabelled ligands in various preparations. The data suggest a multiplicity of binding properties, for example, competitive and noncompetitive binding to substrates as well as different levels of ion dependence. The cloning and functional expression of monoamine neurotransmitter transporter cDNAs in heterologous systems revealed that their substrate recognition and inhibitor sensitivities may be compared with those of native transporters (Table 2). Furthermore, site-directed mutagenesis and chimera formation provide more details on the transporter ligand interaction.

As discussed above, the aspartate residue (D79) in the TM1 of rat DAT, which is conserved in monoamine neurotransmitter transporters but not in other neurotransmitter transporters, is necessary for both substrate transport and cocaine binding, suggesting that the negatively-charged moiety of this residue is involved in 
the binding of ligand with protonated amine groups (63). However, replacing two serine residues in TM7 with alanine or glycine reduced dopamine uptake with less effect on binding of the cocaine analogue CFT (63). The authors therefore concluded that although cocaine competitively blocks dopamine uptake, recognition sites for dopamine and cocaine on DAT do not completely overlap. Thus, compounds can be developed that specifically inhibit cocaine binding to this transporter while they spare transport activity.

Using the range of sensitivity to inhibitors such as nortryptilline, desipramine, nisoxetine, mazindol or amphetamine, Giros and colleagues (87) and Buck and Amara (88) constructed a series of DAT-NET chimeras with which to analyze the structural requirements for ligand recognition.

Both groups suggested that the most influential determinants of DAT and NET selectivity for reuptake inhibitors lie within a domain spanning TMs5-7. Replacing TMs5 -7 of the NET within those of DAT produced a 1000 -fold increase in the $K_{i}$ for tricyclic antidepressants. Buck and Amara (88) further demonstrated that TMs1-3 influence the interactions with cocaine and selective blockers of DAT including GBR12909 and GBR12935. Giros et al. (87) have shown that substituting the sequence from TMs5-8 of DAT into NET results in a dramatic loss of affinity for cocaine. These results suggest that cocaine interactions involve several domains.

Chimera with a junction at TMs4-8 transported less substrate (less than $10 \%$ of wild-type transporters), suggesting that these regions are also important for substrate translocation or recognition. Therefore, it should be noted that decreased affinity for a substrate may cause specific interactions with inhibitors to be underestimated.

In a similar type of study, Barker et al. (89) analyzed rat-human SERT chimeras. Tricyclic antidepressants were more potent at human SERT, while $d$-amphetamine was more potent at rat SERT. These authors isolated a region in or near TM12 implicated in determining species-specific differences among inhibitor sensitivities.

Another approach to identify specific regions important for cocaine action in DAT has been taken by Vaughan (90), who performed controlled proteolysis of photoaffinity-labeled protein and epitope-specifically immunoprecipitated the labeled fragments. The results showed that 1-[2-(diphenylmethoxy)ethyl]-4-[2-(4-azido-3${ }^{[25}$ I] iodophenyl)ethyl]piperazine ([ ${ }^{125}$ I]DEEP), a piperazine analog, is photoincorporated into the amino half of the DAT near the first two TM helices, whereas $3 \beta$ ( $p$-chlorophenyl)tropane-2 $\beta$-carboxylic acid 4 '-azido-3'$\left[{ }^{125} I\right]$ iodophenylethyl ester ( $\left[{ }^{125} I\right]$ RTI-82), a cocaine analogue, labels the carboxy-terminal region of the protein between TMs4 -12 . These results partially correlated with the finding in chimera studies.

The importance of polar amino acids located in TM4 and TM5 was suggested by the finding that replacing the tyrosine residues in TM4 and TM5 (Y251, Y273) with alanine reduced dopamine and $\mathrm{MPP}^{+}$uptake, as well as CFT binding (91-93). The kinetics of dopamine and $\mathrm{MPP}^{+}$uptake changed in a different manner in Y251 and Y273 mutants (reduced capacity without affecting affinity in the former and reduced affinity without affecting capacity in the latter), but were altered in parallel for dopamine and $\mathrm{MPP}^{+}$. For further clarification, the tyrosine residues were replaced with phenylalanine (Y251F, Y273F) or serine (Y251S, Ys73S), based upon whether the hydrophobic interaction of the phenyl ring or hydrogenbonding by the hydroxy group of tyrosine is important for transporter-ligand interaction. The Y251F mutant had properties similar to those of the wild-type, whereas the Y273F mutant did not. Transport and ligand recognition were reduced in the Y251S and Y273S mutants. These results suggested that the tyrosine located in TM4 recognizes dopamine, $\mathrm{MPP}^{+}$and cocaine at its phenylring by hydrophobic interaction. This conclusion is highly speculative and further investigations are needed.

The major goals of DAT-related anti-cocaine medication research and development include the elucidation of selective compounds that could provide cocaine antagonism at concentrations that still allow dopamine transport. Such agents would allow the umimpeded movement of dopamine in the joint presence of dopamine, cocaine and the agent, and thus represent high potential as medications for treating cocaine addiction.

The information provided by the mutation and chimera studies showed that cellular expression systems of cloned DAT cDNAs allows assessment of the relative potencies of drugs in inhibiting dopamine uptake and CFT binding in the same preparations in parallel. Kitayama et al. (93) have demonstrated that some compounds more potently inhibit CFT binding than dopamine uptake. By analyzing the structural features of these compounds, a new series of candidates for cocaine medication will be developed.

\section{Short-term and long-term modification of transporters: Regulatory mechanisms}

Alterations in monoamine neurotransmitter transporters have been identified in a number of neurological and psychiatric disorders. Changes involve the kinetics of transport or the number of active transporters at the cell surfaces. Therefore, regulation could occur at the level of transcription or translation or by posttranslational modifications in physiological and disease states.

Transporters are glycoproteins in which sugar accounts for $20-30 \%$ of their total molecular mass. Cloned trans- 
porters revealed $\mathrm{N}$-linked glycosylation sites located in the 2nd putative extracellular loop. DAT protein appears to have a different molecular mass in the striatum and nucleus accumbens (94), where dopamine uptake kinetics and cocaine sensitivity differ $(95,96)$. These results suggested that glycosylation of the transporter plays an important role in functions. Evidence indicating that glycosylation is required for optimal stability of the transporter in the membrane, but not for substrate transport or ligand binding per se has been found in rat SERT (97) and DAT, using site-directed mutagenesis to replace the asparagine residue located in the 2nd extracellular loop with alanine (S. Kitayama et al., unpublished observation).

The second large extracellular loop contains several cysteine residues, some of which are conserved within the neurotransmitter transporter family. Studies with thiol-modifying reagents suggest that cysteine plays an important role in the function of transporters. Wang et al. (98) have demonstrated altered dopamine uptake and CFT binding in COS cells expressing DAT cysteine mutants, suggesting that the sulfide moieties of the $2 \mathrm{nd}$ loop cysteine residues are crucial to DAT expression and function.

The amino acid sequences deduced from cloned neurotransmitter transporter cDNAs contain a consensus for multiple phosphorylation sites (see Fig. 1 and Table 1). Studies on the regulation of (monoamine) neurotransmitter transporter functions have been performed by examining the effects of agents that activate the signal transduction pathway, resulting in protein kinase activation.

Cholera toxin, forskolin or agents that increase cAMP levels up-regulate SERT in the human placental choriocarcinoma cell line JAR (99). The effect was specific to SERT, because the taurine uptake was not affected. Kinetic analyses showed an increase in $V_{\max }$ and a decrease in $\mathbf{K}_{\mathrm{m}}$. Further experiments by these groups (100) suggest that SERT is modified by a cAMP-dependent protein kinase at the transcriptional level. On the other hand, cholera toxin decreases serotonin uptake in PC12 cells in a kinetically complex manner, suggesting that regulation may be cell-specific (101).

Dopamine uptake by cultured rat hypothalamic cells is enhanced by increasing the intracellular cAMP (102). It is known that the kinetics of dopamine uptake in the terminals of the tuberoinfundibular neurons markedly differ from those of the nigrostriatal and mesolimbic systems (103). In situ and Northern hyblidization has shown that hypothalamic neurons display much less DAT mRNA than that found in nigra compacta neurons (47). Overall, the hypothalamic neuron may display a subclass of DAT unlike the cloned DAT, the expression of which is regulated by cAMP-dependent protein kinase. Tian et al. (104) demonstrated that forskolin and 8-br-cAMP inhibited GABA uptake but did not alter dopamine uptake in striatal synaptosome preparations. They suggested that structurely related GAT and DAT may be post-translationally regulated in a different manner.

PKC activation inhibits SERT function in human platelets (105) and cultured endothelial cells (106). Data indicating that the effects of phorbol ester, an activator of PKC, on SERT function are characterized by a decrease in $V_{\max }$ without affecting $K_{m}$, suggest that regulation occurs at the transcription level.

Kitayama et al. (107) examined the effect of phorbol esters on dopamine transport and CFT binding in COS cells expressing rat DAT. They found that PKC activation alters DAT functions in both ligand (cocaine) recognition and substrate translocation.

Contrary to the inhibitory effect of PKC activation on monoamine transporters, Corey et al. (108) have demonstrated that GAT expressed in Xenopus laevis oocytes is upregulated by PKC activation. They suggested that a modulatory mechanism for neurotransmitter transporters is mediated by the regulated subcellular redistribution of the transporter.

The SERT function in placental choriocarcinoma cells (109) and that of DAT in rat striaum (110) may be regulated in a calmodulin-dependent manner. Jayarthi et al. (109) demonstrated that the calmodulin antagonist 1,3dihydro-1-[1-((4-methyl-4H,6H-pyrrolo[1,2-a][4,1]-benzoxapin-4-yl)methyl)-4-piperindinyl]-2 $H$-benzimidazol-2one (CGS9343B), as well as W-7 and calmidazolium, specifically reduced serotonin transport in association with a decrease in the maximal velocity and in the affinities for serotonin in the human placental choriocarcinoma cell lines JAR and BeWo. CGS9343B did not affect the steady state levels of the SERT mRNAs or the transporter density in the plasma membrane using the SERTspecific ligand $\left[{ }^{125}\right.$ I]RTI-55. These results suggested that SERT is regulated by a calmodulin-dependent process in human placental choriocarcinoma cells involving posttranslational modification, most likely the phosphorylation/dephosphorylation, of the transporter protein.

The $\mathrm{Ca}^{2+}$-dependent enhancement of dopamine uptake by rat striatal synaptosomes has been described by Uchikawa et al. (110). Since the dopamine uptake enhanced by $\mathrm{Ca}^{2+}$ was inhibited by the $\mathrm{Ca}^{2+} /$ calmodulindependent protein kinase II inhibitor $\mathrm{KN}-62$ and the calmodulin antagonist $\mathrm{W}-7$ but not by PKC inhibitors, they suggested that the effect is mediated by the activation of calmodulin-dependent protein kinases. The $\mathrm{Ca}^{2+}$. mediated modification of serotonin uptake was also reported in human platelets, although the calmodulindependent protein kinase seems not to be involved in 
its regulation (111).

Direct evidence of transporter phosphorylation has been demonstrated by Casado et al. (112) using the glutamate transporter. By incubating the glutamate transporter purified from pig brain with PKC and $\left[\gamma_{-32}^{32} \mathrm{P}\right] \mathrm{ATP}$, the transporter was predominantly phosphorylated at serine residues. Furthermore, replacing serine 113 in GLT-1, a glial glutamate transporter cloned from the rat brain, with asparagine abolished the stimulative effect of the phorbol ester phorbol 12-myristate 13-acetate (PMA) on glutamate uptake in transfected HeLa cells.

Several antibodies to the neurotransmitter transporters are available, so more direct evidence regarding the regulation of transporter by protein kinases in vitro and in vivo and its physiological role in neural transmission will soon be obtained.

Although modulation of the transporter in disease states or in drug treatments such as therapy with antidepressants have been studied in depth, the regulatory roles of the normal physiological mechanism have not been sufficiently evaluated. Miller and Hoffman (113) have examined the effect of the receptor-activated second messenger on SERT in rat basophilic leukemia cells (RBL 2H3), which contain SERT and the $G$ protein-coupled $\mathrm{A}_{3}$ adenosine receptor. Activating the $\mathrm{A}_{3}$ adenosine receptor increased serotonin uptake with an increased velocity, whereas the binding of paroxetine, a SERTspecific ligand was unchanged. Data from studies of inhibitors of the nitric oxide (NO) generating system or of cGMP-dependent kinase suggest that after stimulating the $A_{3}$ adenosine receptor, transport is elevated through the generation of the gaseous second messenger NO and a subsequent elevation in cGMP. The changes in transport seem to be due to a direct modification of SERT, possibly by phosphorylation, which appears to alter the rates of transport.

Yamashita et al. (114) investigated the effect of nicotine on dopamine uptake in COS cells expressing rat DAT and in PC12 cells. Nicotine did not affect dopamine uptake in the COS cells, but reduced it in PC12 cells. The inhibitory effect of nicotine is mediated by the nicotinic acetylcholine receptor and is not affected by removing $\mathrm{Ca}^{2+}$ from the medium or by K-252a, a broad and specific protein kinase inhibitor. Although the exact mechanism of dopamine uptake inhibition by nicotine is unknown, the decreased $\mathrm{Na}^{+}$gradient resulting from the $\mathrm{Na}^{+}$influx through the nicotinic acetylcholine receptor channel caused by nicotine may be involved.

Neurotransmitter transporters are also regulated at the level of gene expression. Neuronal activity or drugs may affect the modulation of transporter expression in various states such as transcription, translation or sorting as well as the stability of the transporter protein in the plasma membrane. Kinetic studies of serotonin transport and uptake inhibitor binding have suggested that chronic treatment with mood stabilizing drugs and psychomotor stimulants have a time-dependent regulatory effect on the monoamine transporter system (1). The decreased SERT mRNA steady state concentrations caused by the longterm administration of antidepressants suggests that chronic treatment with re-uptake inhibiting antidepressants is associated with SERT regulation at the level of gene expression; this may contribute to the neuroadaptative mechanism that underlies their therapeutic efficacy $(115,116)$.

Contrary to the downregulation of SERT mRNA expression by chronic antidepressant treatment, desipramine, a tricyclic antidepressant which preferentially blocks NET, increased NET mRNA in the locus ceruleus in rats treated both short-term ( 2 days) and chronically (4 weeks) (117). The effects did not seem to be mediated via the $\alpha_{2}$-receptor (118).

Acute and chronic exposure to drugs of abuse such as cocaine alter the monoamine neurotransmitter transporter system in which DAT inhibition participates in cocaine reinforcement (119). Data from studies of DAT mRNA expression during and after exposure to cocaine are consistent with the results that showed downregulated dopamine uptake and inhibitor binding $(120,121)$. Xia et al. (122) have reported that DAT mRNA levels decreased 4 $\mathrm{hr}$ after the last injection of a chronic regimen of cocaine administration but not at $72 \mathrm{hr}$. Cerruti et al. (123) have examined the effect upon DAT mRNA expression of withdrawing cocaine after repeated administration. Ten days after stopping a 2-week administration, DAT binding levels were decreased in the nucleus accumbens but not in the striatum. This correlated with the decrease in DAT mRNA restricted to the area projecting into the nucleus accumbens and other limbic areas, suggesting that the regulation of DAT gene expression by dopamine uptake inhibition is involved in the rewarding effect of cocaine.

Receptor-operated regulation of neurotransmitter transporter gene expression has been demonstrated in cultured rat brain neurons that expresss NET and the angiotensin II receptor (124). Angiotensin II stimulated the NET system both acutely and chronically. The former involved the activation of preexisting transporters, while the latter involved NET gene transcription and translation. They also suggested that the upregulation of NET mRNA expression may be mediated via PKC activity followed by activation of the $c$-fos gene. These results support the general concept that the expression of neurotransmitter transporter genes is under physiological control. A demonstration of immediate early gene response elements in the neurotransmitter transporter 
gene is required to confirm the mechanism through which receptors control the expression of neurotransmitter transporter genes.

\section{Concluding remarks}

Recent studies on neurotransmitter transporters with various approaches including the functional expression of cloned transporters show that the categories for channel and transporter are ambiguous. There is an increasing body of evidence indicating that transporters function with channel-like properties. These include several conductive states with gating mechanisms, the neurotransmitter that is to be transported modulates transport of ions and even in the absence of a substrate, the neurotransmitter transporter functions in passing ions in association with potential changes in the plasma membrane. Therefore, transporters act as neurotransmitter receptor ion channels or voltage-sensitive ion channels. They differ from receptor ion channels in that a neurotransmitter is transported after it is recognized and differ from voltagesensitive ion channels in that voltage-sensitive activation of transporter is directly modulated by neurotransmitter.

The multiplicity of transporter functions involved in physiological and disease states should be addressed. Transporters function in a bi-directional mode that terminates and initiates neurotransmission. For example, receptors of the inhibitory neurotransmitter GABA, which hyperpolarize cells via $\mathrm{Cl}^{-}$influx, also depolarize them via a $\mathrm{Cl}^{-}$efflux when the electrochemical gradient for $\mathrm{Cl}^{-}$is reversed. This indicates that GABA is not only inhibitory, but also excitatory. By analogy to this, reversed transport of the neurotransmitter by transporter causes various physiological and pathological symptoms. The drugs that act on the GAT to inhibit uptake cause GABA to accumulate in the synaptic cleft, which then enhances the inhibitory effect of GABA. However, inhibiting the GAT could also increase excitability when it releases GABA to maintain basal inhibitory tone.

There are several subtypes of transporter for same neurotransmitter specifically localized in cells such as neuron and glia where each transporter might play a different role. Three glutamate transporters have been identified in the rat, including the astroglial transporters GLAST and GLT-1 and the neuronal transporter EAAC1. Rothstein et al. (125) have demonstrated by means of chronic antisense oligonucleotide administration, that the selective loss of the glial glutamate transporters GLAST and GLT-1 elevates the extracellular glutamate levels and produces the neurodegeneration characteristic of excitotoxicity, as well as progressive paralysis. On the other hand, the loss of the neuronal glutamate transporter EAAC1 does not elevate extracellular glutamate and produces only mild neurotoxicity. These results suggest that glial glutamate transporters provide most of the functional glutamate transport essential for extracellular glutamate clearance and thus prevents glutamate neurotoxicity.

The release of monoamine neurotransmitters through their transporters has been shown in vitro and in vivo under various conditions in which transporter functions were altered by drugs including cocaine, amphetamine or nicotine. The various effects of drugs on the transportermediated uptake and release of monoamine neurotransmitter might participate in the action of addictive drugs. Giros et al. (126) have demonstrated that disruption of the mouse DAT gene by homologous recombination causes spontaneous hyperlocomotion despite major adaptive changes, such as a decrease in neurotransmitter and receptor levels. In the absence of DAT, dopamine remains in the extracellular space at least 100 times longer than in the presence of a full complement of DAT, explaining the biochemical basis for the hyperdopaminergic phenotype and demonstrating the critical role of the transporter in regulating neurotransmission. The lack of further locomotor activity or stereotypy in response to treating homozygote mice with cocaine and amphetamine suggests that DAT is the major molecular target of these psychostimulants and that it mediates their behavioral and molecular action on dopamine transmission. DAT knockout mice should be an excellent tool with which to study and develop drugs used to manage dopaminergic dysfunction. It is also of particular interest that the uptake of neurotransmitters into synaptic vesicles and subsequent storage participate in the molecular dynamics of neurotransmitters at nerve endings. Gene targetting the vesicular monoamine transporters should resolve this issue.

The concept of transporters, channels and/or receptors should be re-assessed. The implications of the new concept of transporters for physiological and disease states promise more understanding about the regulation of synaptic transmission.

\section{REFERENCES}

1 Langer ZS and Schoemaker $\mathrm{H}$ : Effects of antidepressants on monoamine transporters. Prog Neuropsychopharmacol Biol Psychiat 12, 193-216 (1988)

2 Javitch AJ, D'Amato JR, Strittmatter MS and Snyder HS: Parkinsonism-inducing neurotoxin, $N$-methyl-4-phenyl-1,2,3,6tetrahydropyridine: Uptake of the metabolite $N$-methyl-4phenylpyridine by dopamine neurons explains selective toxicity. Proc Natl Acad Sci USA 82, 2173-2177 (1985)

3 Snyder HS and D'Amato JR: MPTP: A neurotoxin relevant to the pathophysiology of Parkinson's disease. Neurology 36, $250-258$ (1986) 
4 Ritz CM, Lamb JR, Goldberg RS and Kuhar JM: Cocaine receptors on dopamine transporters are related to self-administration of cocaine. Science 237, 1219-1223 (1987)

5 Guastella J, Nelson N, Nelson H, Czyzyk L, Keynan S, Miedel MC, Davidson N, Lester $H$ and Kanner B: Cloning and expression of a rat brain GABA transporter. Science 249, 1303-1306 (1990)

6 Pacholczyk T, Blakely DR and Amara GS: Expression cloning of a cocaine- and antidepressant-sensitive human noradrenaline transporter. Nature 350, 350-354 (1991)

7 Shimada S, Kitayama S, Lin C-L, Patel A, Nanthakumar E, Gregor P, Kuhar M and Uhl G: Cloning and expression of a cocaine-sensitive dopamine transporter complementary DNA. Science 254, 576-578 (1991)

8 Kilty EJ, Lorang D and Amara GS: Clonig and expression of a cocaine-sensitive rat dopamine transporter. Science 254, $578-579$ (1991)

9 Giros B, Mestikawy ES, Bertrand L and Caron GM: Cloning and functional characterization of a cocaine-sensitive dopamine transporter. FEBS Lett 295, 149-154 (1991)

10 Usdin BT, Mezey E, Chen C, Brownstein JM and Hoffman JB: Cloning of the cocaine-sensitive bovine dopamine transporter. Proc Natl Acad Sci USA 88, 11168-11171 (1991)

11 Hoffman JB, Mezey E and Brownstein JM: Cloning of a serotonin transporter affected by antidepressants. Science $\mathbf{2 5 4}$, $579-580$ (1991)

12 Blakely DR, Berson EH, Fremeau TR, Caron GM, Peek MM, Prince $\mathrm{KH}$ and Bradley $\mathrm{CC}$ : Cloning and expression of a functional serotonin transporter from rat brain. Nature 354, 66-70 (1991)

13 Liu QR, Nelson H, Mandiyan S, Lopez-Corcura B and Nelson $\mathrm{N}$ : Cloning and expression of a glycine transporter from mouse brain. FEBS Lett 305, 110-114 (1992)

14 Guastella J, Brecha N, Weigmann C, Lester HA and Davidson $\mathrm{N}$ : Cloning, expression, and localization of a rat brain highaffinity glycine transporter. Proc Natl Acad Sci USA 89, $7189-7193$ (1992)

15 Smith KE, Borden LA, Hartig PR, Branchek T and Weinshank RL: Cloning and expression of a glycine transporter reveal colocalization with NMDA receptors. Neuron 8, 927-935 (1992)

16 Smith KE, Borden LA, Wang CD, Hartig PR, Branchek TA and Weinshank RL: Cloning and expression of a high affinity taurine transporter from rat brain. Mol Pharmacol 42, 563-569 (1992)

17 Liu QR, L'pez-Corcura B, Nelson H, Mandiyan S and Nelson $\mathrm{N}$ : Cloning and expression of a cDNA encoding the transporter of taurine and $\beta$-alanine in mouse brain. Proc Natl Acad Sci USA 89, 12145 - 12149 (1992)

18 Uchida S, Kwon HM, Yamauchi A, Preston AS, Marumo F and Handler JS: Molecular cloning of the cDNA for an MDCK cell $\mathrm{Na}^{+}$- and $\mathrm{Cl}^{-}$-dependent taurine transporter that is regulated by hypertonicity. Proc Natl Acad Sci USA 89, 8230-8234 (1992)

19 Fremeau RT, Caron MC and Brakely RD: Molecular cloning and expression of a high-affinity L-proline transporter expressed in putative glutamatergic pathways of rat brain. Neuron $\mathbf{8}$, 915-926 (1992)

20 Yamauchi A, Uchida S, Kwon HM, Preston AS, Robey RB, Garcia-Perez A, Burg MB and Handler JS: Cloning of a $\mathrm{Na}^{\text {' }}$ - and $\mathrm{Cl}^{-}$-dependent betaine transporter that is regulated by hypertonicity. J Biol Chem 267, 649-652 (1992)

21 Mayser W, Schloss P and Betz H: Primary structure and functional expression of a choline transporter expressed in the rat nervous system. FEBS Lett 305, 31-36 (1992)

22 Storck T, Schulte S, Hofmann K and Stoffel W: Structure, expression, and functional analysis of a $\mathrm{Na}^{+}$-dependent glutamate/aspartate transporter from rat brain. Proc Natl Acad Sci USA 89, 10955 - 10959 (1992)

23 Pines G, Danbolt NC, Bjørås M, Zhang Y, Bendahan A, Eide L, Koepsell H, Storm-Mathisen J, Seeberg E and Kanner BI: Cloning and expression of a rat brain L-glutamate transporter. Nature 360, 464-467 (1992)

24 Kanai $Y$ and Hediger MA: Primary structure and functional characterization of a high-affinity glutamate transporter. Nature 360, 467-471 (1992)

25 Alfonso A, Grundahl K, Duerr JS, Han HP and Rand JB: The Caenorhabditis elegans unc-17 gene: a putative vesicular acetylcholine transporter. Science 261, 617-619 (1993)

26 Liu Y, Peter D, Roghani A, Schuldiner S, Prive GG, Eisenberg D, Brecha N and Edwards RH: A cDNA that suppresses MPP ${ }^{+}$ toxicity encodes a vesicular amine transporter. Cell 70, 539551 (1992)

27 Erickson JD, Eiden LE and Hoffman BJ: Expression cloning of a reserpine-sensitive vesicular monoamine transporter. Proc Natl Acad Sci USA 89, 10993 - 10997 (1992)

28 Stern-Bach Y, Keen JN, Bejerano M, Steiner-Mordoch S, Wallach M, Findlay JB and Schuldiner S: Homology of a vesicular amine transporter to a gene conferring resistance to 1-methyl-4-phenylpyridinium. Proc Natl Acad Sci USA 89, 9730-9733 (1995)

29 Vandenbergh JD, Persico MA and Uhl RG: A human dopamine transporter cDNA predicts reduced glycosylation, displays a novel repetitive element and provides racially-dimorphic Taq1 RFLPs. Mol Brain Res 15, 161 - 166 (1992)

30 Giros B, Mestikawy S, Godinot N, Zheng K, Han H, YangFeng $\mathrm{T}$ and Caron MG: Cloning, pharmacological characterization, and chromosome assignment of the human dopamine transporter. Mol Pharmacol 42, 383-390 (1992)

31 Lingen B, Bruss $\mathbf{M}$ and Bonisch $\mathrm{H}$ : Cloning and expression of the bovine sodium- and chloride-dependent noradrenaline transporter. FEBS Lett 342, 235-238 (1994)

32 Ramanoorthy S, Bauman LA, Moore RK, Han H, Yang-Feng T, Chang SA, Ganapathy V and Blakely DR: Antidepressantand cocaine-sensitive human serotonin transporter: Molecular cloning, expression, and chromosomal localization. Proc Natl Acad Sci USA 90, 2542-2546 (1993)

33 Lesch K-P, Wolozin LB, Estler CH, Murphy LD and Riederer P: Isolation of a CDNA encoding the human brain serotonin transporter. J Neural Transm 91, 67-72 (1993)

34 Gregor P, Patel A, Shimada S, Lin CL, Rochelle JM, Kitayama S, Seldin MF and Uhl GR: Murine serotonin transporter: sequence and localization to chromosome 11. Mamm Genome 4, $283-284$ (1993)

35 Corey LJ, Quick WM, Davidson N, Lester AH and Guastella J: A cocaine-sensitive Drosophila serotonine transporter: Cloning, expression, and electrophysiological characterization. Proc Natl Acad Sci USA 91, 1188 - 1192 (1994)

36 Demchyshyn LL, Pristupa BZ, Sugamori SK and Barker LE: Cloning, expression, and localization of a chloride-facilitated, 
cocaine-sensitive serotonin transporter from Drosophila melanogaster. Proc Natl Acad Sci USA 91, 5158- 5162 (1994)

37 Vandenbergh JD, Persico MA, Hawkins LA, Griffin AC, Li X, Jabs WE and Uhl RG: Human dopamine transporter gene (DAT1) maps to chromosome 5 p15.3 and displays a VNTR. Genomics 14, 1104-1106 (1992)

38 Lossie CA, Vandenbergh JD, Uhl RG and Camper AS: Localization of the dopamine transporter gene, Dat 1, on mouse chromosone 13. Mamm Genome 5, 117-118 (1994)

39 Donovan MD, Vandenbergh JD, Perry PM, Bird SG, Ingersoll R, Nanthakumar E and Uhl RG: Human and mouse dopamine transporter genes: conservation of 5 -flanking sequence elements and gene structures. Mol Brain Res 30, 327-335 (1995)

40 Gelernter J, Kruger S, Pakstis JA, Pacholoczyk T, Sparkes SR, Kidd KK and Amara S: Assignment of the norepinephrine transporter protein (NET1) locus to chromosome 16. Genomics 18, 690-692 (1993)

41 Bruss M, Kunz J, Lingen B and Bonisch H: Chromosomal mapping of the human gene for the tricyclic antidepressantsensitive noradrenaline transporter. Hum Genet 91, 278-280 (1993)

42 Lesch K-P, Balling U, Gross J, Strauss K, Wolozin LB, Murphy LD and Riederer $P$ : Organization of the human serotonin transporter gene. J Neural Transm 95, 157-162 (1994)

43 Gelernter J, Pakstis JA and Kidd KK: Linkage mapping of serotonin transporter protein gene SLC6A4 on chromosome 17. Hum Genet 95, 677-680 (1995)

44 Nakatome M, Honda K, Islam NM, Terada M, Yamazaki M, Kuroki H, Ogura $\mathrm{Y}$, Bai $\mathrm{H}$ and Wakasugi $\mathrm{C}$ : Amplication of DAT1 (human dopamine transporter gene) 3' variable region in the Japanese population. Hum Hered 45, 262-265 (1995)

45 Muramatsu $T$ and Higuchi S: Dopamine transporter gene polymorphism and alcoholism. Biochem Biophys Res Commun 211, $28-32$ (1995)

46 Kelsoe JR, Remick RA, Sadovnick AD, Kristhjarnarson $H$, Flodman P, Spence MA, Morison M, Mroczkowski-Parker Z, Bergesch P, Rapaport MH, Mirow AL, Brakely RD, Helgason $\mathrm{T}$ and Egeland JA: Genetic linkage of bipolar disorder and serotonin transporter. Am J Med Genet 67, 215-217 (1996)

47 Shimada S, Kitayama S, Walther D and Uhl G: Dopamine trasnporter mRNA: dense expression in ventral midbrain neurons. Mol Brain Res 13, 359-362 (1992)

48 Augood JS, Westmore K, McKenna JP and Emson CP: Co-expression of dopamine transporter mRNA and tyrosin hydroxylase mRNA in ventral mesencephalic neurones. Mol Brain Res 20, $328-334$ (1993)

49 Freed C, Revay R, Vaughan AR, Kriek E, Grant S, Uh1 RG and Kuhar JM: Dopamine transporter immunoreactivity in rat brain. J Com Neurol 359, 340-349 (1995)

50 Ciliax JB, Heilman C, Demchyshyn LL, Pristupa BZ, Ince E, Hersch MS, Niznik BH and Levey IA: The dopamine transporter; immunochemical characterization and localization in brain. J Neurosci 15, 1714-1723 (1995)

51 Eymin C, Charnay Y, Greggio B and Bouras C: Localization of noradrenaline trasnporter mRNA expression in the human locus coeruleus. Neurosci Lett 193, $41-44$ (1995)

52 Melikian EH, McDonald KJ, Gu H, Rudnick G, Moore RK and Blakely DR: Human norepinephrine transporter. J Biol Chem 269, 12290-12297 (1994)
53 Lorang D, Amara GS and Simerly BR: Cell-type-specific expression of catecholamine transporters in the rat brain. J Neurosci 14, 4903-4914 (1994)

54 Austin CM, Bradley CC, Mann JJ and Blakely DR: Expression of serotonin transporter messenger RNA in the human brain. $J$ Neurochem 62, 2362-2367 (1994)

55 Qian Y, Melikian EH, Rye BD, Levey IA and Blakely DR: Identification and characterization of antidepressant-sensitive serotonin transporter proteins using site-specific antibodies. J Neurosci 15, 1261- 1274 (1995)

56 Kimelberg HK: Occurrence and functional significance of serotonin and catecholamine uptake by astrocytes. Biochem Pharmacol 35, 2273-2281 (1986)

57 Kitayama S, Shimada S and Uhl GR: Parkinsonism-inducing neurotoxin $\mathrm{MPP}^{+}$: uptake and toxicity in nonneuronal $\mathrm{COS}$ cells expressing dopamine transporter cDNA. Ann Neurol 32, $109-111$ (1992)

58 Pifl C, Giros B and Caron MG: Dopamine transporter expression confers cytotoxicity to low doses of the parkinsonisminducing neurotoxin 1-methyl-4-phenylpyridinium. J Neurosci 13, 4246-4253 (1993)

59 Gu H, Wall SC and Rudnick G: Stable expression of biogenic amine transporters reveals differences in inhibitor sensitivity, kinetics, and ion dependence. J Biol Chem 269, 7124-7130 (1994)

60 Strader CD, Sigal IS, Resgister RB, Candelore MR, Rands E and Dixon RAF: Identification of residues required for ligand binding to the $\beta$-adrenergic receptor. Proc Natl Acad Sci USA 84, 4384-4388 (1987)

61 Strader CD, Sigal IS, Candelore MR, Rands E, Hill WS and Dixon RAF: Conserved aspartic acid residues 79 and 113 of the $\beta$-adrenergic receptor have different roles in receptor function. J Biol Chem 263, 10267-10271 (1988)

62 Strader CD, Sigal IS and Dixon RA: Structural basis of $\beta-$ adrenergic receptor function. FASEB J 3, 1825-1832 (1989)

63 Kitayama S, Shimada S, Xu H, Markham L, Donovan DM and Uhl RG: Dopamine transporter site-directed mutations differently alter substrate transport and cocaine binding. Proc Natl Acad Sci USA 89, 7782 (1992)

64 Kitayama S, Wang J-B and Uhl RG: Dopamine transporter mutants selectively enhance $\mathrm{MPP}^{-}$transport. Synapse 15, $58-62$ (1993)

65 Buck JK and Amara GS: Chimeric dopamine-norepinephrine transporters delineate structural domains influencing selectivity for catecholamines and 1-methyl-4-phenylpridinium. Proc Natl Acad Sci USA 91, $12584-12588$ (1994)

66 Kitayama S, Morita $K$ and Dohi $T$ : Cocaine inhibits the release of $\mathrm{MPP}^{+}$but not dopamine through the rat dopamine transporter. Eur J Pharmacol 309, 107-109 (1996)

67 Levi $G$ and Raiteri M: Carrier-mediated release of neurotransmitters. Trend Neurosci 16, 415-419 (1993)

68 Eshleman JA, Henningsen AR, Neve AK and Janowsky A: Release of dopamine via the human transporter. Mol Pharmacol 45, 312-316 (1994)

69 Wall CS, Gu H and Rudnick G: Biogenic amine flux mediated by cloned transporters stably expressed in cultured cell lines: amphetamine specificity for inhibition and efflux. Mol Pharmacol 47, 544-550 (1995)

70 During JM, Ryder MK and Spencer DD: Hippocampal GABA transporter function in temporal-lobe epilepsy. Nature 376 , 
174- 177 (1995)

71 Horton RW, Collins JF, Anlezark GM and Meldrum BS: Convulsant and anticonvulsant actions in DBA/2 mice of compounds blocking the reuptake of GABA. Eur J Pharmacol 59, $75-83$ (1979)

72 Gonsalves SF, Twitchell B, Harbaugh RE, Krogsgaard-Larsen $P$ and Schousboe A: Anticonvulsant activity of intracerebroventricularly administered glial GABA uptake inhibitors and other GABA mimetics in chemical seizure models. Epilepsy Res 4, 34-41 (1989)

73 Rudnick $\mathrm{G}$ and Clark J: From synapse to vesicle: the reuptake and storage of biogenic amine neurotransmitters. Biochim Biophys Acta 1144, 249-263 (1993)

74 Barbour B, Szatkowski M, Ingledew N and Attwell D: Arachidonic acid induces a prolonged inhibition of glutamate uptake into glial cells. Nature 342, $918-920$ (1989)

75 Malchow RP and Rips $\mathrm{H}$ : Effect of $\gamma$-aminobutyric acid on skate retinal horizontal cells: Evidence for an electrogenic uptake mechanism. Proc Natl Acad Sci USA 87, 8945-8949 (1990)

76 Bruns D, Engert F and Lux H-D: A fast activating presynaptic reuptake current during serotonergic transmission in identified neurons of Hirudo. Neuron 10, 559-572 (1993)

77 Kavanaugh PM, Arriza LJ, North AR and Amara GS: Electrogenic uptake of $\gamma$-aminobutyric acid by a cloned transporter expressed in Xenopus oocytes. J Biol Chem 267, 22007-22009 (1992)

78 Klockner U, Storck T, Conradt M and Stoffel W: Electrogenic L-glutamate uptake in Xenopus laevis oocytes expressing a cloned rat brain L-glutamate/L-aspartate transporter (GLAST1). J Biol Chem 268, 14594-14596 (1992)

79 Mager S, Naeve J, Quick M, Labarca C, Davidson N and Lester AH: Steady states, charge movements, and rates for a cloned GABA transporter expressed in Xenopus oocytes. Neuron 10, $177-188$ (1993)

80 Mager S, Min C, Henry JD, Chavkin C, Hoffman JB, Davidson $\mathrm{N}$ and Lester $\mathrm{AH}$ : Conducting states of a mammalian serotonin transporter. Neuron 12, 845-859 (1994)

81 Galli A, Deffelice JL, Duke B-J, Moore RK and Blakely DR: Sodium-dependent norepinephrine-induced currents in norepinephrine-transporter-transfected HEK-293 cells blocked by cocaine and antidepressants. J Exp Biol 198, 2197-2212 (1995)

82 Ungell AL, Oberleithner $\mathrm{H}$ and Graefe KH: Chloride-dependence of the potency of inhibitors of the neuronal noradrenaline carrier in the rat vas deferens. Naunyn Schmiedebergs Arch Pharmacol 339, 65-70 (1989)

83 Jayanthi LD, Prasad PD, Ramamoorthy S, Mahesh VB, Leibach FH and Ganapathy V: Sodium- and chloride-dependent, cocaine-sensitive, high-affinity binding of nisoxetine to the human placental norepinephrine transporter. Biochemistry 32, $12178-12185$ (1993)

84 Lester HA, Mager S, Quick MW and Corey JL: Permeation properties of neurotransmitter transporters. Annu Rev Pharmacol Toxicol 34, 219-249 (1994)

85 Fairman WA, Vandenberg RJ, Arriza JL, Kavanaugh MP and Amara SG: An excitatory amino-acid transporter with properties of a ligand-gated chloride channel. Nature 375, 599-603 (1995)

86 Kitayama S, Morita $\mathrm{K}$ and Dohi $\mathrm{T}$ : Uptake and release of dopamine through the rat dopamine transporter expressed in
Xenopus laevis oocytes. Evaluation by voltammetric measurement of intracellular dopamine concentration. Neurosci Lett 211, 132 - 134 (1996)

87 Giros B, Wang Y-M, Suter S, Mcleskey BS, Pifl C and Caron GM: Delineation of discrete domains for substrate, cocaine, and tricyclic antidepressant interactions using chimeric dopamine-norepinephrine transporters. J Biol Chem 269, 1598515988 (1994)

88 Buck JK and Amara GS: Structural domains of catecholamine transporter chimeras involved in selective inhibition by antidepressants and psychomotor stimulants. Mol Pharmacol 48, $1030-1037$ (1995)

89 Barker LB, Kimmel LH and Blakely DR: Chimeric human and rat serotonin transporters reveal domains involved in recognition of transporter ligands. Mol Pharmacol 48, 799-807 (1995)

90 Vaughan AR: Photoaffinity-labeled ligand binding dopamins on dopamine transporters identified by peptide mapping. Mol Pharmacol 47, 956-964 (1995)

91 Wang JB, Davis S and Uhl GR: Dopamine transporter sitedirected mutants identify residues selectively important for cocaine recognition. Soc Neurosci Abstract 19, 745 (1993)

92 Davis S, Wang JB and Uhl GR: The phenyl ring of tyrosine 250 of the dopamine transporter is required for high-affinity binding of cocaine analogs. Soc Neurosci Abstract 20, 922 (1994)

93 Kitayama S, Morita K, Dohi T, Wang JB, Davis SC and Uhl GR: Dissection of dopamine and cocaine binding sites on the rat dopamine transporter expressed in COS cells. In Cellular and Molecular Mechanisms of Drugs of Abuse: Cocaine, Ibogaine, and Substituted Amphetamines, Edited by Ali SF and Takahashi Y, Ann NY Acad Sci, The New York Academy of Science, New York (in press)

94 Lew R, Vaughan R, Simantov R, Wilson A and Kuhar JM: Dopamine transporters in the nucleus accumbens and the striatum have different apparent molecular weights. Synapse $\mathbf{8}$, $152-153$ (1991)

95 Jones RS, Garris AP, Kilts DC and Wightman MR: Comparison of dopamine uptake in the basolateral amygdaloid nucleus, caudate-putamen, and nucleus accumbens of the rat. J Neurochem 64, 2581-2589 (1995)

96 Jones RS, Garris AP and Wightman MR: Different effects of cocaine and nomifensine on dopamine uptake in the caudateputamen and nucleus accumbens. J Pharmacol Exp Ther 274, 396-403 (1995)

97 Tate GC and Blakely DR: The effect of $N$-linked glycosylation on activity of the $\mathrm{Na}^{+}$- and $\mathrm{Cl}^{-}$-dependent serotonin transporter expressed using recombinant baculovirus in insect cells. J Biol Chem 269, 26303-26310 (1994)

98 Wang BJ, Moriwaki A and Uhl RG: Dopamine transporter cysteine muntans: Second extracellular loop cysteines are required for transporter expression. J Neurochem 64, 1416-1419 (1995)

99 Cool RD, Leibach HF, Bhalla KV, Mahesh BV and Ganapathy V: Expression and cyclic AMP-dependent regulation of a high affinity serotonin transporter in the human placental choriocarcinoma cell line (JAR). J Biol Chem 266, 15750-15757 (1991)

100 Ramamoorthy S, Cool RD, Mahesh BV, Leibach HF, Melikian EH, Blakely DR and Ganapathy V: Regulation of the human serotonin transporter. J Biol Chem 268, 21626-21631 (1993)

101 King CS, Tiller AA, Chang S-SA and Lam M-KD: Differential regulation of the imipramine-sensitive serotonin transporter 
by cAMP in human JAR choriocarcinoma cells, rat $\mathrm{PC1} 2$ pheochroocytoma cells, and C33-14-B1 transgenic mouse fibroblast cells. Biochem Biophys Res Commun 183, 487-491 (1992)

102 Kadowaki K, Hirota K, Koike K, Ohmichi M, Kiyama H, Miyake $A$ and Tanizawa $O$ : Adenosine 3',5'-cyclic monophosphate enhances dopamine accumulation in rat hypothalamic cell culture containing dopaminergic neurons. Neuroendocrinology 52, 256-261 (1990)

103 Annunziato L, Leblanc P, Kordon C and Weiner RI; Differences in the kinetics of dopamine uptake in synaptosome preparations of the median eminence relative to other dopaminergically innervated brain regions. Neuroendocrinology 31, $316-320(1980)$

104 Tian Y, Kapatos G, Granneman GJ and Bannon JM: Dopamine and $\gamma$-aminobutyric acid transporters: differential regulation by agents that promote phosphorylation. Neurosci Lett 173, 143 - 146 (1994)

105 Anderson MG and Horne CW: Activators of protein kinase C decrease serotonin trasnport in human platelets. Biochim Biophys Acta 1137, $331-337$ (1992)

106 Myers LC, Lazo SJ and Pitt RB: Translocation of protein kinase $\mathrm{C}$ is associated with inhibition of 5-HT uptake by cultured endothelial cells. Am J Physiol 257, L253-L258 (1989)

107 Kitayama S, Dohi T and Uhl RG: Phorbol esters alter functions of the expressed dopamine transporter. Eur J Pharmacol 268, 115- 119 (1994)

108 Corey LJ, Davidson N, Lester AH, Brecha N and Quick WM: Protein kinase $\mathrm{C}$ modulates the activity of a cloned $\gamma$-aminobutyric acid transporter expressed in xenopus oocytes via regulated subcellular redistribution of the transporter. J Biol Chem 269, $14759-14767$ (1994)

109 Jayanthi DL, Ramamoorthy S, Mahesh BV, Leibach HF and Ganapathy V: Calmodulin-dependent regulation of the catalytic function of the human serotonin transporter in placental choriocarcinoma cells. J Biol Chem 269, 14424-14429 (1994)

110 Uchilkawa T, Kiuchi U, Yura A, Nakachi N, Yamazaki Y, Yokomizo $\mathrm{C}$ and Oguchi $\mathrm{K}$ : $\mathrm{Ca}^{2+}$-dependent enhancement of $\left[{ }^{3} \mathrm{H}\right]$ dopamine uptake in rat striatum: Possible involvement of calmodulin-dependent kinases. J Neurochem 65, 2065-2071 (1995)

111 Nishio $H$, Nezasa $K$ and Nakata $Y$ : Role of calcium ion in platelet serotonin uptake regulation. Eur J Pharmacol 288, $149-155$ (1995)

112 Casado M, Bendahan A, Zafra F, Danbolt CN, Aragón C, Giménez $C$ and Kanner IB: Phosphorylation and modulation of brain glutamate transporters by protein kinase C. J Biol Chem 268, 27313-27317 (1993)

113 Miller JK and Hoffman JB: Adenosine $\mathrm{A}_{3}$ receptors regulate serotonine transport via nitric oxide and cGMP. J Biol Chem 269, 27351-27356 (1994)

114 Yamashita H, Kitayama S, Zhang Y-X, Takahashi T, Dohi T and Nakamura S: Effect of nicotine on dopamine uptake in COS cells possessing the rat dopamine transporter and in PC12 cells. Biochem Pharmacol 49, 742-745 (1995)

115 Lesch PK, Aulakh SC, Wolozin LB, Tolliver JT, Hill LJ and Murphy LD: Regional brain expression of serotonin transporter mRNA and its regulation by reuptake inhibiting antidepressants. Mol Brain Res 17, 31-35 (1993)

116 Kuroda $\mathrm{Y}$, Watanabe $\mathrm{Y}$ and McEwen SB: Tianeptine decreases both serotonin transporter $\mathrm{mRNA}$ and binding sites in rat brain. Eur J Pharmacol 268, R3-R5 (1994)

117 Szot P, Ashliegh EA, Kohen R, Dorsa DM and Veith R: Norepinephrine transporter mRNA is elevated in the locus coeruleus following short- and long-term desipramine treatment. Brain Res 618, 308-312 (1993)

118 Shores MM, Szot $\mathbf{P}$ and Veith CR: Desipramine-induced increase in norepinephrine transporter $\mathrm{mRNA}$ is not mediated via $\alpha_{2}$ receptors. Mol Brain Res 27, 337-341 (1992)

119 Kuhar MJ, Ritz MC and Boja JW: The dopamine hypothesis of the reinforcing properties of cocaine. Trends Neurosci 14, 299-302 (1991)

120 Izenwasser S and Cox BM: Daily cocaine treatment produces a persistent reduction of $\left[{ }^{3} \mathrm{H}\right]$ dopamine uptake in vitro in rat nucleus accumbens but not in striatum. Brain Res 531, 338-341 (1990)

121 Pilotte NS, Sharpe LG and Kuhar MJ: Withdrawal of repeated intravenous infusions of cocaine persistently reduces binding to dopamine transporters in the nucleus accumbens of Lewis rats. J Pharmacol Expr Ther 269, 963-969 (1994)

122 Xia Y, Goebel JD, Kapatos G and Bannon JM: Quantitation of rat dopamine transporter mRNA: Effects of cocaine treatment and withdrawal. J Neurochem 59, 1179-1182 (1992)

123 Cerruti C, Pilotte SN, Uhl G and Kuhar JM: Reduction in dopamine transporter mRNA after cessation of repeated cocaine administration. Mol Brain Res 22, 132-138 (1992)

124 Lu D, Yu K, Paddy RM, Rowland EN and Raizada KM: Regulation of norepinephrine transport system by angiotensin 2 in neuronal cultures of normotensive and spontaneously hypertensive rat brains. Endocrinology 137, $763-772$ (1996)

125 Rothstein JD, Dykes-Hoberg M, Pardo CA, Bristol LA, Jin L, Kuncl RW, Kanai Y, Hediger MA, Wang Y, Schielke JP and Welty DF: Knockout of glutamate transporters reveals a major role for astroglial transport in excitotoxicity and clearance of glutamate. Neuron 16, 675-686 (1996)

126 Giros B, Jaber M, Jones SR, Wightman RM and Caron MG: Hyperlocomotion and indifference to cocaine and amphetamine in mice lacking the dopamine transporter. Nature 379, 606-612 (1996) 